\title{
Structural Requirements for Molecular Recognition by fMLP Analogs Receptors: Comparative Conformational Analysis of (for-Met-Leu-Phe-OMe) and its Thioamide Analog (for-Met-Leu $\psi[\mathrm{CSNH}]$ Phe-OMe)
}

\author{
Chakib Ameziane Hassani, ${ }^{1, \star}$ Mourad Houssat, ${ }^{1}$ Jamal Eddine Hazm ${ }^{2}$ \\ and Ahmed Harrach ${ }^{3}$ \\ ${ }^{1}$ Laboratory of Applied Chemistry LCA, Faculty of Sciences and Technology, Sidi Mohamed Ben Abdellah \\ University PB 2202, Fez, Morocco. \\ ${ }^{2}$ Laboratory of Mechanical Engineering, Faculty of Sciences and Technology, Sidi Mohamed Ben Abdellah \\ University PB 2202, Fez, Morocco. \\ ${ }^{3}$ Laboratory of Condensed Matter Chemistry, Faculty of Sciences and Technology, Sidi Mohamed Ben Abdellah \\ University PB 2202, Fez, Morocco. \\ * Corresponding author: E-mail: chakib-ameziane@hotmail.com \\ Telephone Number: $+212-663503010$
}

Received: 09-07-2018

\begin{abstract}
In order to determine the structural requirements of fMLP analogs receptors, this work presents the results of a comparative conformational analysis of the active chemotactic peptide (formyl-Met-Leu-Phe-OMe) and its inactive analog (formyl-MetLeuభ [CSNH] Phe-OMe) using the theoretical method PEPSEA. This study showed that a $\gamma$ turn structure centered on the central residue is the native structure of the chemotactic peptide fMLP analogs, where both $\mathrm{CO}$ (formyl) and $\mathrm{NH}$ (central residue) groups are available and ready to interact with the receptor. The inactive analog $\mathrm{fML}{ }^{\mathrm{S}} \mathrm{P}-\mathrm{OMe}$ prefers instead a $\gamma$ turn structure centered on the Met residue, where the two groups cited above are not available for this interaction. Our results and those of literature enable us to propose the "induced fit" model of Burgen for the molecular recognition process. Consequently, the activity of fMLP analogs chemotactic peptides would not be related to a specific secondary structure ( $\beta$ turn, $\gamma$ turn or extended....) but rather to the freedom and the availability of the $\mathrm{CO}$ (formyl) and the $\mathrm{NH}$ group at position 2.
\end{abstract}

Keywords: Chemotactic peptide; fMLP analogs; Conformational analysis; Molecular recognition.

\section{Introduction}

The chemotactic peptide fMLP has received much interest in recent years, due to the key role that it plays in our body, particularly in the immune system, it induces the release of the polymorphonuclear leukocytes, the superoxide $\mathrm{O}^{-}$and the lysozyme enzyme of the neutrophil. ${ }^{1-4}$ It is considered to be a very active agent. ${ }^{5}$ The structure-activity relationship was established as well as the specificity of the receptors located on the neutrophil cell surface. ${ }^{6-9}$

The studies carried out by Freidinger et al, ${ }^{10-13}$ which consist to create Lactam bridges in peptide structures and by Perdih et al to synthetis of $\alpha$-amino-organometallic acids, ${ }^{14}$ have shown the success of peptidomimetic in the field of the design of new therapeutic agents. The aim of these modifications is to limit the degrees of freedom and capture the bioactive conformation of a native peptide. In the case of fMLP analogs, several modifications have been made. ${ }^{15-19}$ The influence of the terminal groups has been studied, and it has been demonstrated that esterification of the carboxylic C-terminal does not affect the biological activity of the molecule. ${ }^{20}$ On the other hand, the substitution of the formyl group at N-terminal by the tert-butylcarbonyl group (Boc) results in a total loss of activity. ${ }^{21,22}$ In 1985 Sauvé et al tried to introduce changes at the back- 
bone by replacing amide bonds by thioamide ones which are more resistant to enzymatic hydrolysis. ${ }^{15}$ The synthesized analogs were tested and the biological activities were evaluated using the release of lysozyme from human neutrophils. The replacement of the amide bond at the Methionine by a thioamide bond was carried out and resulted in a dramatic loss of activity. ${ }^{3}$ The comparative conformational study of the two molecules formyl-Met-Leu-Phe$\mathrm{OMe}$ and formyl-Met $\psi(\mathrm{CSNH}] \mathrm{Leu}-\mathrm{Phe}-\mathrm{OMe}$ showed that the active chemotactic peptide must have the formyl group free of any intramolecular interaction in order to be available for the formation of the complex with the receptor. ${ }^{16}$ The substitution of the central residue with disubstituted $\alpha-\alpha$ residues such as aminocyclohexanecarboxylic acid (Acc6) and aminocyclopentanecarboxylic acid (Acc5) resulted in an increase in activity. ${ }^{23}$ Using a theoretical method, our comparative conformational studies of the parent peptide with these lathers have revealed that the native conformation of fMLP chemotactic peptides is the $\beta$-turn structure, despite the unavailability of the $\mathrm{CO}(-$ formyl)..$^{24,25}$

In order to continue our investigations on the structural requirements of the fMLP chemotactic receptors, ${ }^{16,24,25}$ we present, through this work, a comparative conformational study of the parent active peptide (formylMet-Leu-Phe-OMe) and its thioamide analog (formylMet-Leu $\psi(\mathrm{CSNH})-\mathrm{Phe}-\mathrm{OMe})$ devoid of any activity. ${ }^{3}$ The main objective is to explain the difference in activity between the two tripeptides (fig. 1), to propose the native conformation of fMLP analogs and to determine the structural requirements for molecular recognition by their receptors.

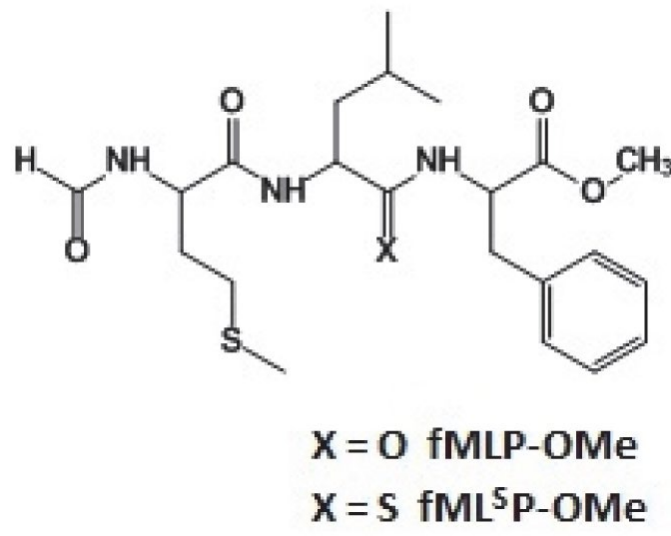

Fig 1. Structure of fMLP-OMe and $\mathrm{AML}^{\mathrm{S}} \mathrm{P}-\mathrm{OMe}$.

\section{Methods and Materials}

The method used in this study is called PEPSEA (PEPtidic SEArch). It was developed by Michel et al in the structural chemistry laboratory of the Sherbrooke University, ${ }^{26}$ and it has shown its effectiveness in the theoretical conformational studies of several peptide molecules and their structure-activity relationship. ${ }^{16,24-32}$ This approach is based on the fact that the structural thermodynamic and statistical properties of a molecular system can be deduced only from a population presenting its conformational space. The principle of PEPSEA consists of generating a population of conformations that characterize a particular peptidic sequence. Rather than striving for global minima, the population of conformers is randomly generated using the subtractive method, ${ }^{33}$ which generates numbers between 0 and 1 . These numbers are then converted into values between $-180^{\circ}$ and $+180^{\circ}$ and assigned to different torsional angles that define a starting structure of the analyzed molecule. After the random generation step, a minimization of energy to the closest minimum is performed using the conjugate gradient algorithm. ${ }^{34}$ The convergence criterion was set to $10^{-4}$, terminating the calculation when the module of the vector constituted by the first derivatives becomes less than this value. Finally, a statistical analysis is applied to this population of minima to deduce the thermodynamic and structural properties of the peptides studied; this new approach is applied with the PEPSEA program.

The force field used by the PEPSEA program to compute the conformational energy is ECEPP/2 "Empirical Calculation Energy Program for Peptide".35 This force field uses rigid geometry to represent the amino acid residues of the polypeptidic chain. The conformational energy function is the sum of four terms: Electrostatic term $E_{\text {ele }}$, 12-6 Lennard -Jones term $\mathrm{E}_{\mathrm{LJ}}$, hydrogen-bond term $\mathrm{E}_{\mathrm{hb}}$ and the torsion term $\mathrm{E}_{\text {tor }}$

$$
\mathrm{E}_{\text {conf }}=\mathrm{E}_{\text {ele }}+\mathrm{E}_{\mathrm{Lj}}+\mathrm{E}_{\mathrm{hb}}+\mathrm{E}_{\text {tor }}
$$

The PEPSEA program uses the specific parameters of each residue (atomic coordinates, geometrical and energy parameters...) to describe the geometry of the peptidic molecules. The force field ECEPP/2 possesses the parameters of the 26 amino acid residues and of terminal protecting groups commonly found in proteins. However, for the thioleucyl residue that is not included in the database, we used the parameters proposed by Michel et al to consider the thioamide bond. ${ }^{16}$

It is worth noting that the dielectric constant used by PEPSEA is $\mathrm{D}=2$ (Different of that in vacuous). According to Momany et al, ${ }^{36}$ this effective dielectric constant $\mathrm{D}=2$ is equivalent to the experimental dielectric constant (set between 4 and 8) similar to that of proteins in a polar medium.

As all endogenous peptides, the tripeptides under investigation in this study are constituted by the sequence of amino acids, all in L configuration.

\section{1. Experimental Procedure}

The PEPSEA program described above carried out the conformational search and the localization of the most 
stable conformers. For each two considered tripeptides, 20.000 conformers were randomly generated and energy minimized to the closest minima. During this generation, all torsion angles are allowed to vary except the amide bonds; $\omega$ (Met), $\omega$ (Leu) and $\omega$ (Phe) which are fixed at $180^{\circ}$. We have carefully ensured that the 20.000 generated conformations subjected to minimization are the same for both molecules. For each tripeptide, the first 100 conformers of lower conformational energies were submitted to a second energy minimization allowing all dihedral angles to be modified. For each of those 100 minima, the Hessian matrix was calculated and the free energy was evaluated. ${ }^{37}$ The resulting conformers were sorted by increasing values of the free energies, and then clustered into groups of conformers having the same structural characteristics ( $\beta$ turn, $\gamma$ turn or extended....).

The calculation of energy and minimization were performed on station HP pro-Intel (R) Core(TM) i3-3240 $\mathrm{CPU} @ 3.40 \mathrm{GHz}$ at the faculty of sciences and techniques of Fez.

\section{Results}

For the evaluation of the minimization efficiency, we have studied the energy distributions of the 20.000 conformers of the 2 molecules: fMLP-OMe and $\mathrm{fML}^{\mathrm{S}} \mathrm{P}-\mathrm{OMe}$. The next figure (Fig 2) represents these distributions.

Of these graphs, it can be seen that the conformers generated and minimized are grouped in a single distribution having a Gaussian form for the 2 molecules studied. This observation confirms the effectiveness of the minimization process.

Tables 1 and 2 give the conformational characteristics of the fifty most stable conformers obtained after the second minimization for each tripeptide. Conformers were numbered by increasing free energy values. The conformational energies $(\Delta \mathrm{E})$ are given relative to the global minima: conformer $7\left(\mathrm{E}_{0}=-5.65 \mathrm{Kcal} / \mathrm{mol}\right)$ for $\mathrm{fM}$ $\mathrm{LP}-\mathrm{OMe}$ and conformer $3\left(\mathrm{E}_{0}=-4.65 \mathrm{Kcal} / \mathrm{mol}\right)$ for $\mathrm{fML}$ ${ }^{S} \mathrm{P}-\mathrm{OMe}$. Free energy values $(\Delta \mathrm{G})$ have been computed relative to the same conformers at $\mathrm{T}=300 \mathrm{~K}$, the entropic contributions $(-\mathrm{T} \Delta \mathrm{S})$ and statistical weights $(\mathrm{Wi})$ are also presented. The structural characteristics have been given for each conformer indicating the presence or not of an intramolecular hydrogen bond between the different donors and acceptors. The torsion angles for the fifty conformers of the parent peptide and the thioamide analog are listed in Appendices 1 and 2 respectively, with their conformational energies in $\mathrm{Kcal} / \mathrm{mol}$.

The conformational analysis of the fifty most stable conformers of the parent peptide fMLP-OMe (table 1) shows that it can adopt varied conformational structures, which the majority can be distributed into four classes:

The first class is represented by seventeen conformers adopting a $\beta$ turn structure centered on Met and Leu.
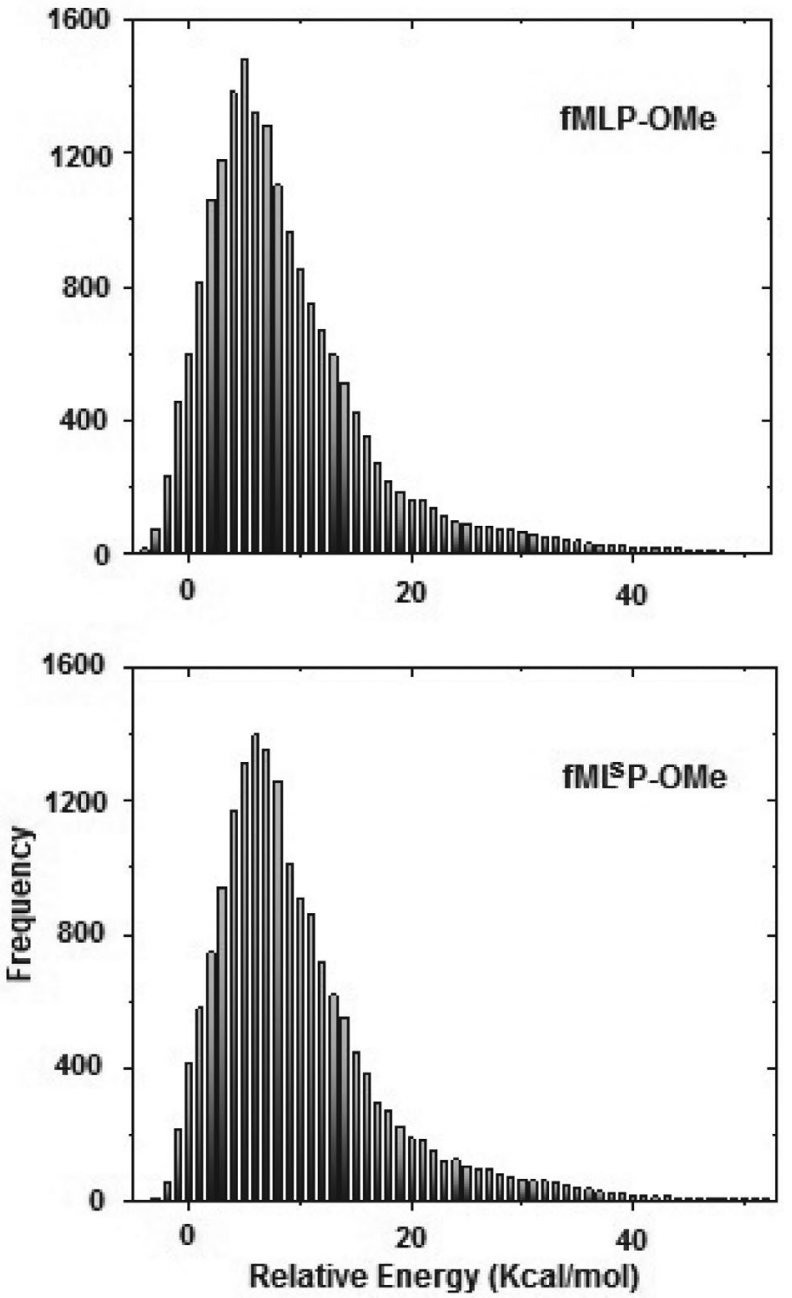

Fig 2: Energy distributions of minimized conformers of fMLP-OMe and $\mathrm{AML}^{\mathrm{S}} \mathrm{P}-\mathrm{OMe}$.

Five of them are stabilized by a hydrogen bond between the $\mathrm{CO}$ formyl and $\mathrm{NH}$ of Phe: conformers $(2,4,28,42$ and $43)$, and twelve adopt this structure but without that the hydrogen bond being established: conformers $(3,5,6,11$, $12,13,15,18,23,29,36$ and 37). Fig.3a gives a stereoscopic superposition view of the conformers belonging to this class, from which we can see that they are similar, mainly at the backbone level. The Met and Leu side chains are oriented in two different ways, while the Phe residue can rotate more freely. It is worth noting that several authors have suggested this structure for many fMLP-OMe analogs, using spectroscopic X-ray and NMR methods as well as molecular modeling studies. ${ }^{21,23-25,38-42 .}$ Fig.4a shows a stereoscopic view of the superposition of our $\beta$ turn structure (conformer 2, table 1) with those found by Bardi for the Boc-Met-Aib-Phe-OMe analog ${ }^{21}$, Rathore for the f-Met-AC8C-Phe-OMe ${ }^{38}$ and Zecchini for the f-Met$\Delta^{\mathrm{Z}}$ Leu-Phe-OMe ${ }^{39}$. This figure shows that there is a great similarity at the backbone level and that the only differences with our structure lie just at the side chains orientation of Methionine and Phenylalanine. 
Table 1. Conformational characteristics of fMLP a :

\begin{tabular}{|c|c|c|c|c|c|c|c|c|c|}
\hline & Conf & $\Delta \mathbf{G I}^{\mathbf{b}}$ & $\Delta \mathrm{EI}^{\mathrm{c}}$ & $-\mathrm{T} \Delta \mathrm{S}^{\mathrm{d}}$ & $\mathrm{WI}^{\mathrm{e}}$ & Formyl & Met & Leu & Phe \\
\hline \multirow{17}{*}{$\begin{array}{l}\tilde{y} \\
\tilde{\Xi} \\
\tilde{\omega} \\
\vec{\omega}\end{array}$} & 2 & -0.77 & 1.76 & -2.54 & 0.1035 & $\mathrm{CO}$ & & & $\mathrm{NH}$ \\
\hline & 3 & -0.39 & 0.59 & -0.98 & 0.0543 & & & & \\
\hline & 4 & -0.15 & 1.56 & -1.71 & 0.0363 & $\mathrm{CO}$ & & & $\mathrm{NH}$ \\
\hline & 5 & -0.02 & 1.63 & -1.66 & 0.0294 & & & & \\
\hline & 6 & -0.01 & 2.42 & -2.44 & 0.0289 & & & & \\
\hline & 11 & 0.15 & 2.63 & -2.49 & 0.0221 & & & & \\
\hline & 12 & 0.17 & 1.71 & -1.54 & 0.0211 & & & & \\
\hline & 13 & 0.18 & 2.61 & -2.43 & 0.0210 & & & & \\
\hline & 15 & 0.30 & 2.13 & -1.83 & 0.0172 & & & & \\
\hline & 18 & 0.41 & 1.53 & -1.12 & 0.0142 & & & & \\
\hline & 23 & 0.53 & 2.14 & -1.61 & 0.0116 & & & & \\
\hline & 28 & 0.74 & 1.15 & -0.41 & 0.0081 & $\mathrm{CO}$ & & & $\mathrm{NH}$ \\
\hline & 29 & 0.77 & 1.91 & -1.14 & 0.0078 & & & & \\
\hline & 36 & 0.93 & 2.66 & -1.73 & 0.0059 & & & & \\
\hline & 37 & 0.95 & 2.15 & -1.20 & 0.0057 & & & & \\
\hline & 42 & 1.03 & 2.67 & -1.64 & 0.0050 & $\mathrm{CO}$ & & & $\mathrm{NH}$ \\
\hline & 43 & 1.06 & 2.11 & -1.05 & 0.0048 & $\mathrm{CO}$ & & & $\mathrm{NH}$ \\
\hline \multirow{12}{*}{$\begin{array}{l}y \\
\tilde{z} \\
\tilde{J} \\
\overrightarrow{\tilde{J}}\end{array}$} & 1 & -0.81 & 1.43 & -2.24 & 0.1103 & & $\mathrm{CO}$ & & $\mathrm{NH}$ \\
\hline & 16 & 0.34 & 2.34 & -2.00 & 0.0159 & & $\mathrm{CO}$ & & $\mathrm{NH}$ \\
\hline & 19 & 0.45 & 2.68 & -2.23 & 0.0133 & & $\mathrm{CO}$ & & $\mathrm{NH}$ \\
\hline & 20 & 0.46 & 1.73 & -1.27 & 0.0131 & & $\mathrm{CO}$ & & $\mathrm{NH}$ \\
\hline & 21 & 0.48 & 1.54 & -1.06 & 0.0126 & & & & \\
\hline & 33 & 0.87 & 1.97 & -1.09 & 0.0065 & & $\mathrm{CO}$ & & $\mathrm{NH}$ \\
\hline & 38 & 0.95 & 2.78 & -1.83 & 0.0057 & & & & \\
\hline & 41 & 1.01 & 1.41 & -0.39 & 0.0052 & & $\mathrm{CO}$ & & $\mathrm{NH}$ \\
\hline & 44 & 1.06 & 2.79 & -1.73 & 0.0048 & & $\mathrm{CO}$ & & $\mathrm{NH}$ \\
\hline & 46 & 1.11 & 2.49 & -1.38 & 0.0044 & & $\mathrm{CO}$ & & $\mathrm{NH}$ \\
\hline & 48 & 1.18 & 2.59 & -1.42 & 0.0039 & & $\mathrm{CO}$ & & $\mathrm{NH}$ \\
\hline & 49 & 1.29 & 2.34 & -1.05 & 0.0033 & & $\mathrm{CO}$ & & $\mathrm{NH}$ \\
\hline \multirow{7}{*}{ 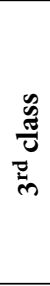 } & 8 & 0.11 & 2.43 & -2.32 & 0.0236 & $\mathrm{CO}$ & & $\mathrm{NH}$ & \\
\hline & 10 & 0.14 & 2.08 & -1.94 & 0.0224 & $\mathrm{CO}$ & & $\mathrm{NH}$ & \\
\hline & 17 & 0.36 & 1.37 & -1.01 & 0.0154 & $\mathrm{CO}$ & & $\mathrm{NH}$ & \\
\hline & 26 & 0.63 & 1.96 & -1.34 & 0.0099 & $\mathrm{CO}$ & & $\mathrm{NH}$ & \\
\hline & 31 & 0.82 & 2.46 & -1.64 & 0.0072 & $\mathrm{CO}$ & & $\mathrm{NH}$ & \\
\hline & 34 & 0.89 & 1.68 & -0.80 & 0.0064 & $\mathrm{CO}$ & & $\mathrm{NH}$ & \\
\hline & 45 & 1.10 & 2.57 & -1.47 & 0.0045 & $\mathrm{CO}$ & & $\mathrm{NH}$ & \\
\hline \multirow{3}{*}{$\equiv$} & 7 & 0.00 & 0.00 & 0.00 & 0.0283 & $\mathrm{CO}$ & $\mathrm{CO}$ & $\mathrm{NH}$ & $\mathrm{NH}$ \\
\hline & 27 & 0.72 & 1.51 & -0.80 & 0.0085 & $\mathrm{CO}$ & $\mathrm{CO}$ & $\mathrm{NH}$ & $\mathrm{NH}$ \\
\hline & 32 & 0.86 & 2.07 & -1.21 & 0.0067 & $\mathrm{CO}$ & $\mathrm{CO}$ & $\mathrm{NH}$ & $\mathrm{NH}$ \\
\hline \multirow{11}{*}{ 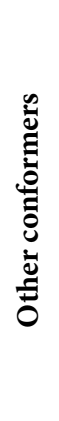 } & 9 & 0.14 & 2.06 & -1.92 & 0.0224 & & & & \\
\hline & 14 & 0.29 & 2.01 & -1.72 & 0.0173 & & & & \\
\hline & 22 & 0.52 & 2.56 & -2.04 & 0.0119 & & & & \\
\hline & 24 & 0.54 & 2.72 & -2.18 & 0.0114 & & & & \\
\hline & 25 & 0.62 & 2.71 & -2.09 & 0.0101 & & & & \\
\hline & 30 & 0.81 & 2.32 & -1.51 & 0.0072 & & & & \\
\hline & 35 & 0.90 & 2.56 & -1.66 & 0.0062 & & & & \\
\hline & 39 & 0.96 & 1.87 & -0.91 & 0.0057 & & & & \\
\hline & 40 & 1.00 & 2.08 & -1.07 & 0.0052 & & & & \\
\hline & 47 & 1.15 & 2.23 & -1.08 & 0.0041 & & & & \\
\hline & 50 & 1.31 & 2.44 & -1.13 & 0.0031 & & & & \\
\hline
\end{tabular}

a. First 50 minimum energy conformations are listed. b. Free energy: $\Delta \mathrm{G}=\mathrm{G}-\mathrm{G}_{0} . \mathrm{G}_{0}$ is the free energy of the conformation having $\mathrm{E}=\mathrm{E}_{0}$. c. Conformational energy: $\Delta \mathrm{E}=\mathrm{E}-\mathrm{E}_{0} . \quad \mathrm{E}_{0}(\mathrm{fMLP})=-5.65 \mathrm{Kcal} / \mathrm{mol}$. d. Entropic contribution: $-\mathrm{T} \Delta \mathrm{S}=\Delta \mathrm{G}-\Delta \mathrm{E}$. e. Statistical weight of conformers: Wi. 
Table 2. Conformational characteristics of $f \mathrm{ML}^{\mathrm{S}} \mathrm{P}^{\mathrm{a}}$ :

\begin{tabular}{|c|c|c|c|c|c|c|c|c|c|}
\hline & Conf & $\Delta \mathbf{G I}^{\mathrm{b}}$ & $\Delta \mathrm{EI}^{\mathrm{c}}$ & $-\mathrm{T} \Delta \mathrm{S}^{\mathrm{d}}$ & $\mathrm{WI}^{\mathrm{e}}$ & Formyl & Met & Thio-Leu & Phe \\
\hline \multirow{20}{*}{ 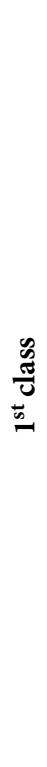 } & 2 & $-0,77$ & 1,76 & -2.54 & 0.1035 & $\mathrm{CO}$ & & & $\mathrm{NH}$ \\
\hline & 2 & -0.43 & 1.78 & -2.21 & 0.0817 & $\mathrm{CO}$ & & & $\mathrm{NH}$ \\
\hline & 4 & -0.01 & 1.78 & -1.79 & 0.0400 & $\mathrm{CO}$ & & & $\mathrm{NH}$ \\
\hline & 5 & 0.10 & 2.61 & -2.51 & 0.0336 & & & & \\
\hline & 6 & 0.19 & 1.96 & -1.77 & 0.0290 & & & & \\
\hline & 8 & 0.22 & 1.81 & -1.59 & 0.0276 & & & & \\
\hline & 12 & 0.50 & 2.46 & -1.96 & 0.0170 & & & & \\
\hline & 16 & 0.83 & 1.98 & -1.15 & 0.0098 & & & & \\
\hline & 18 & 0.90 & 1.38 & -0.48 & 0.0088 & $\mathrm{CO}$ & & & $\mathrm{NH}$ \\
\hline & 19 & 0.90 & 2.06 & -1.16 & 0.0088 & & & & \\
\hline & 20 & 0.90 & 2.13 & -1.23 & 0.0088 & $\mathrm{CO}$ & & & $\mathrm{NH}$ \\
\hline & 21 & 0.95 & 2.23 & -1.28 & 0.0081 & $\mathrm{CO}$ & & & $\mathrm{NH}$ \\
\hline & 23 & 1.07 & 1.34 & -0.27 & 0.0066 & & & & \\
\hline & 24 & 1.09 & 2.30 & -1.21 & 0.0064 & & & & \\
\hline & 25 & 1.12 & 2.81 & -1.7 & 0.0061 & $\mathrm{CO}$ & & & $\mathrm{NH}$ \\
\hline & 26 & 1.12 & 3.00 & -1.88 & 0.0060 & $\mathrm{CO}$ & & & $\mathrm{NH}$ \\
\hline & 31 & 1.44 & 2.01 & -0.57 & 0.0036 & $\mathrm{CO}$ & & & $\mathrm{NH}$ \\
\hline & 41 & 1.81 & 2.20 & -0.39 & 0.0019 & $\mathrm{CO}$ & & & $\mathrm{NH}$ \\
\hline & 47 & 2.08 & 3.15 & -1.07 & 0.0012 & & & & \\
\hline & 49 & 2.16 & 3.10 & -0.94 & 0.0011 & & & & \\
\hline \multirow{2}{*}{ సี } & 1 & -0.87 & 1.42 & -2.3 & 0.1719 & & $\mathrm{CO}$ & & $\mathrm{NH}$ \\
\hline & 13 & 0.83 & 1.98 & -1.15 & 0.0098 & & $\mathrm{CO}$ & & $\mathrm{NH}$ \\
\hline \multirow{17}{*}{ 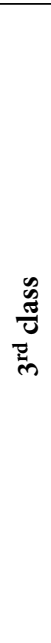 } & 9 & 0.24 & 3.04 & -2.8 & 0.0265 & $\mathrm{CO}$ & & $\mathrm{NH}$ & \\
\hline & 10 & 0.26 & 2.67 & -2.41 & 0.0258 & $\mathrm{CO}$ & & $\mathrm{NH}$ & \\
\hline & 14 & 0.69 & 1.03 & -0.34 & 0.0124 & $\mathrm{CO}$ & & $\mathrm{NH}$ & \\
\hline & 17 & 0.88 & 2.63 & -1.74 & 0.0090 & $\mathrm{CO}$ & & $\mathrm{NH}$ & \\
\hline & 22 & 1.02 & 3.65 & -2.63 & 0.0071 & $\mathrm{CO}$ & & $\mathrm{NH}$ & \\
\hline & 27 & 1.20 & 3.24 & -2.04 & 0.0053 & $\mathrm{CO}$ & & $\mathrm{NH}$ & \\
\hline & 28 & 1.29 & 2.92 & -1.63 & 0.0045 & $\mathrm{CO}$ & & $\mathrm{NH}$ & \\
\hline & 30 & 1.34 & 3.30 & -1.97 & 0.0042 & $\mathrm{CO}$ & & $\mathrm{NH}$ & \\
\hline & 32 & 1.48 & 3.63 & -2.15 & 0.0033 & $\mathrm{CO}$ & & $\mathrm{NH}$ & \\
\hline & 33 & 1.53 & 3.00 & -1.47 & 0.0031 & $\mathrm{CO}$ & & $\mathrm{NH}$ & \\
\hline & 36 & 1.61 & 2.09 & -0.48 & 0.0026 & $\mathrm{CO}$ & & $\mathrm{NH}$ & \\
\hline & 38 & 1.69 & 3.47 & -1.77 & 0.0023 & $\mathrm{CO}$ & & $\mathrm{NH}$ & \\
\hline & 42 & 1.85 & 2.78 & -0.93 & 0.0018 & $\mathrm{CO}$ & & $\mathrm{NH}$ & \\
\hline & 43 & 1.86 & 3.79 & -1.93 & 0.0017 & $\mathrm{CO}$ & & $\mathrm{NH}$ & \\
\hline & 44 & 2.00 & 3.87 & -1.87 & 0.0014 & $\mathrm{CO}$ & & $\mathrm{NH}$ & \\
\hline & 48 & 2.13 & 2.55 & -0.42 & 0.0011 & $\mathrm{CO}$ & & $\mathrm{NH}$ & \\
\hline & 50 & 2.29 & 2.84 & -0.55 & 0.0008 & $\mathrm{CO}$ & & $\mathrm{NH}$ & \\
\hline \multirow{4}{*}{$\equiv$} & 3 & 0.00 & 0.00 & 0.00 & 0.0403 & $\mathrm{CO}$ & $\mathrm{CO}$ & $\mathrm{NH}$ & $\mathrm{NH}$ \\
\hline & 37 & 1.69 & 2.68 & -0.99 & 0.0023 & $\mathrm{CO}$ & $\mathrm{CO}$ & $\mathrm{NH}$ & $\mathrm{NH}$ \\
\hline & 39 & 1.74 & 2.91 & -1.17 & 0.0021 & $\mathrm{CO}$ & $\mathrm{CO}$ & $\mathrm{NH}$ & $\mathrm{NH}$ \\
\hline & 45 & 2.03 & 1.50 & 0.53 & 0.0013 & $\mathrm{CO}$ & $\mathrm{CO}$ & $\mathrm{NH}$ & $\mathrm{NH}$ \\
\hline \multirow{8}{*}{ 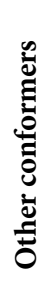 } & 7 & 0.20 & 2.58 & -2.39 & 0.0285 & & & & \\
\hline & 11 & 0.39 & 2.33 & -1.95 & 0.0206 & & & & \\
\hline & 15 & 0.74 & 3.03 & -2.3 & 0.0115 & & & & \\
\hline & 29 & 1.29 & 3.21 & -1.91 & 0.0045 & & & & \\
\hline & 34 & 1.53 & 3.26 & -1.73 & 0.0031 & & & & \\
\hline & 35 & 1.54 & 2.92 & -1.39 & 0.0030 & & & & \\
\hline & 40 & 1.79 & 3.38 & -1.6 & 0.0020 & & & & \\
\hline & 46 & 2.03 & 4.20 & -2.17 & 0.0013 & & & & \\
\hline
\end{tabular}

a. First 50 minimum energy conformations are listed. b. Free energy: $\Delta \mathrm{G}=\mathrm{G}-\mathrm{G}_{0} . \mathrm{G}_{0}$ is the free energy of the conformation having $\mathrm{E}=\mathrm{E}_{0}$. c. Conformational energy: $\Delta \mathrm{E}=\mathrm{E}-\mathrm{E}_{0} . \quad \mathrm{E}_{0}(\mathrm{fMLP})=-5,65 \mathrm{Kcal} / \mathrm{mol}$. d. Entropic contribution: $-\mathrm{T} \Delta \mathrm{S}=\Delta \mathrm{G}-\Delta \mathrm{E}$. e. Statistical weight of conformers: Wi. 
The second class includes twelve conformers characterized by conformations adopting a $\gamma$ turn structure centered on Leu, ten of them are stabilized by an intramolecular hydrogen bond involving the $\mathrm{CO}$ of Met and $\mathrm{NH}$ of Phe $(1,16,19,20,33,41,44,46,48$ and 49). It is interesting to note that the most stable conformer regarding the free energy belongs to this class. Fig.3b presents the stereoscopic superposition view of the conformers of this class, showing that the major variability is at the Met side chain. Using NMR studies, this structure was found for the analogs formyl-Met-Aib-Phe-OH, formyl-Met-Aib-PheOMe, and formyl-Met-Pro-Phe-OMe. ${ }^{15,17,43}$ Following IR and Circular Dichroïsm studies this structure was also found for fMLP-OH, fMLCha-OMe, and fMLP-OMe. ${ }^{44}$ The stereoscopic superposition view of the minimized structure of this latter using the Metropolis Montecarlo

a)
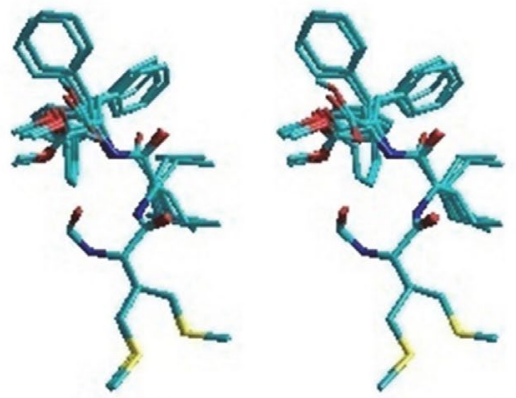

b)
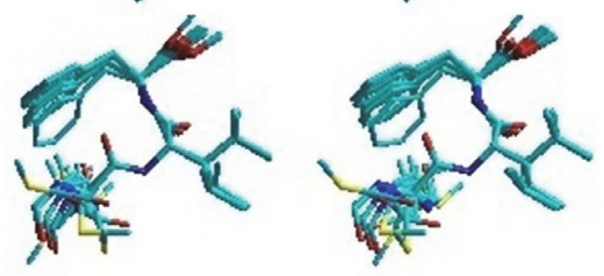

c)
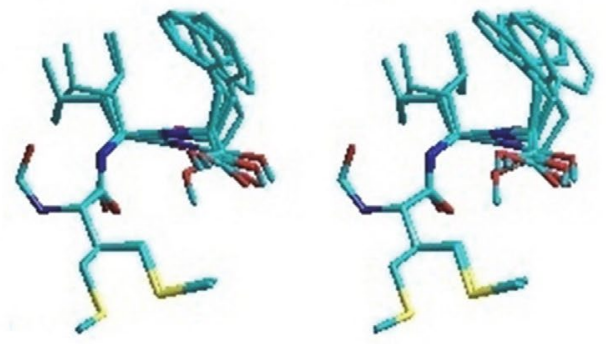

d)

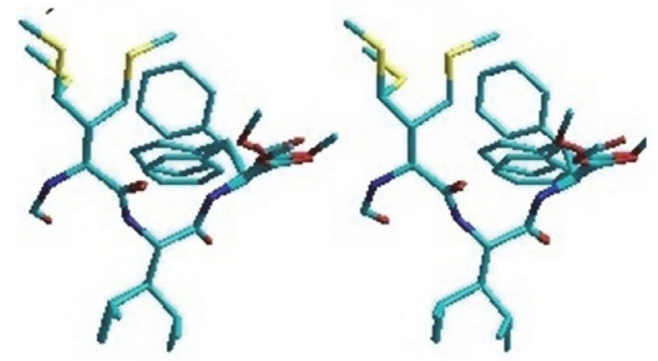

Fig 3: Stereoscopic superposition views of conformers of different classes obtained for fMLP-OMe. a- $\beta$ turn involving CO formyl and $\mathrm{NH}$ Phe. $\mathbf{b}-\gamma$ turn centered on Leu involving $\mathrm{CO}$ of Met and $\mathrm{NH}$ of Phe. $\mathrm{c}-\gamma$ turn centered on Met involving CO formyl and NH of Leu. And d-Double $\gamma$ turns cited above. procedure, ${ }^{45}$ with our $\gamma$ turn structure centered on Leu (conformer 1, table 1) is presented in Fig. $4 \mathrm{~b}$ and shows the great similarity between both structures.

The third class is that of the conformers characterized by the presence of another $\gamma$ turn structure centered this time on the Met residue, and represented by seven conformers $(8,10,17,26,31,34$ and 45$)$. Such structure is stabilized by an intramolecular hydrogen bond involving the CO formyl and NH of Leu. The stereoscopic superposition view of the conformers belong to this class is presented in Fig.3c.

The fourth class gathers structures in a double $\gamma$ turns ( a $\gamma$ turn centered on Met and a $\gamma$ turn centered on Leu at the same time) and include three conformers (7, 27, and 32). The stereoscopic superposition view of the three conformers of this group is given in Fig.3d. Using NMR studies Lucente et al have proposed this structure for the for-Met-Dag-Phe-OMe and for-Met-Cpg-PheOMe analogs. ${ }^{46}$ However, by molecular modeling, Michel et al proposed it as the rigidified precursor for extended conformation after the release of the intramolecular $\mathrm{H}$-bond by external interactions. ${ }^{16}$ The eleven remaining conformers, not belonging to any of the classes above, are mainly stabilized by hydrophobic interactions and characterized by favorable entropic terms, leading to lower

a)
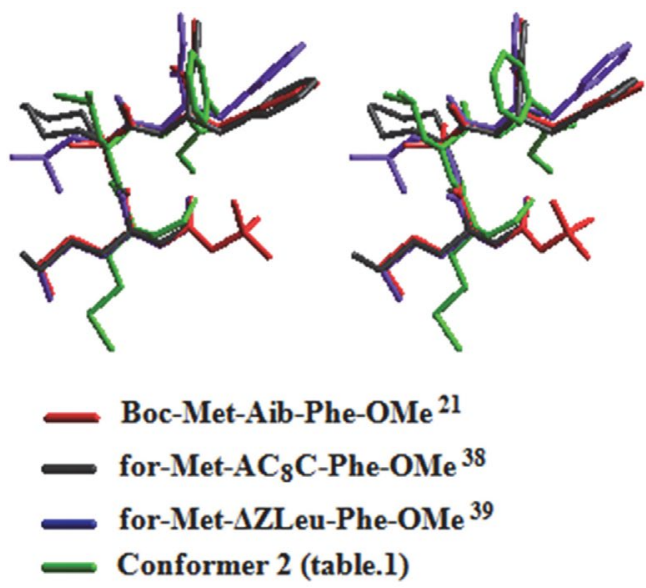

b)
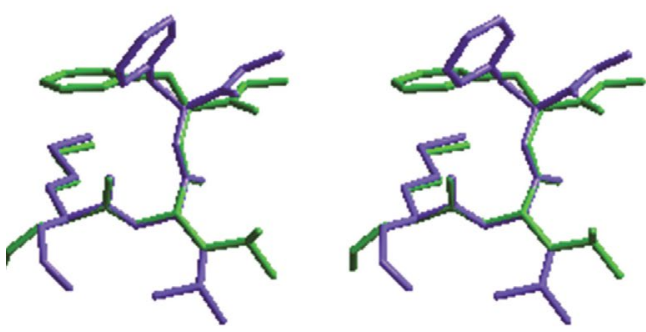

for-Met-Leu-Phe-OMe ${ }^{45}$

Conformer 1 (table.1)

Fig 4: Stereoscopic superposition views of the conformers of this study with those of the literature. $\mathbf{a}-\beta$ turn structures $\mathbf{b}-\gamma$ turn centered on Leu. 
values of free energies. This observation is exemplified by conformer 9.

For the thioamide analog $\mathrm{fML}^{\mathrm{S}} \mathrm{P}-\mathrm{OMe}$, the table 2 shows that preferred structures are distributed on the same classes found previously for AMLP-OMe: 19 for the first class ( $\beta$ turn centered on Met and Leu), 2 for the second $(\gamma$ turn structures centred on Leu), 17 for the third ( $\gamma$ turn structures centred on Met), and 4 for the fourth class (double $\gamma$ turns structures). The stereoscopic superposition views of structures of different classes obtained for this molecule ( $\left.\mathrm{fML}^{\mathrm{S}} \mathrm{P}-\mathrm{OMe}\right)$ are presented in Appendice 3.

\section{Discussion}

The main structural difference that can explain the dramatic fall in $\mathrm{fML}^{\mathrm{S}} \mathrm{P}-\mathrm{OMe}$ activity compared to that of the potent peptide fMLP-OMe can be deduced directly from the comparison of Tables 1 and 2, and considering the number of times where the two pharmacophores, $\mathrm{CO}$ (formyl) and $\mathrm{NH}(\mathrm{Leu})$, are involved in intramolecular hydrogen bonds in both cases. For $\mathrm{fML}^{\mathrm{S}} \mathrm{P}-\mathrm{OMe}$, the $\mathrm{CO}(-$ formyl) group acts as $\mathrm{H}$ acceptor 30 times: $\mathrm{C}^{10} \beta$ turns in 9 cases and $C^{7} \gamma$ turns in 21 cases. On the contrary for the parent peptide fMLP-OMe, the situation is very different: This group is involved in intramolecular hydrogen bonds only 15 times: $C^{10} \beta$ turns in 5 cases and $C^{7} \gamma$ turns in 10 cases. Likewise, the $\mathrm{NH}(\mathrm{Leu})$ is involved in hydrogen bonds 21 times for the fML ${ }^{\mathrm{S}} \mathrm{P}-\mathrm{OMe}$ and only 10 times for the fMLP-OMe. This result is in perfect agreement with the literature which emphasizes the importance of the availability of these two groups in the formation of the substrate-receptor complex. $7,16,39,47-54$

The determination of the native structure of the fMLP analogs can be deduced by comparing the conformational preferences of the two tripeptides for the conformers that we have presented in Table1 and Table 2.

The fact that we found almost the same number of conformers adopting the $\beta$ turn structure $\left(1^{\text {st }}\right.$ class, Fig. $\left.3 a\right)$ for the active peptide fMLP-OMe (17 times), and for its inactive analog $\mathrm{fML}^{\mathrm{S}} \mathrm{P}-\mathrm{OMe}$ (19 times), rejects the proposition that this structure may be the native structure of chemotactic peptides. Indeed, if this structure was native, the thioamide analog would also have been active.

The double $\gamma$ turns structure ( $4^{\text {th }}$ class, Fig.3d) will also be rejected for the same reason, the fMLP-OMe adopts this structure 3 times and the $\mathrm{FML}^{\mathrm{S}} \mathrm{P}-\mathrm{OMe}$, devoid of any activity, adopts it 4 times.

The $\gamma$ turn structure centered on Met ( $3^{\text {rd }}$ class, Fig.3c) is more preferred by the inactive thioamide analog (17 times, table 2 ) compared to the parent peptide ( 7 times, table 1), consequently, its chance to be native becomes weak. We note here that in this structure the two groups $\mathrm{CO}$ (formyl) and $\mathrm{NH}$ (Leu) are involved in an intramolecular hydrogen bond which decreases their availability to participate in the process of molecular recognition and justify the inactivity of the thionated analog. It is very important to remember that the large preference of the fML${ }^{\mathrm{S}} \mathrm{P}-\mathrm{OMe}$ to adopt this structure over than fMLP-OMe is not a stroke of luck, since the generated departure conformations were identical for the two molecules.

The $\gamma$ turn structure centered on Leu ( $2^{\text {nd }}$ class, Fig. $3 b$ ) seems to be the native structure of fMLP analogs; firstly, because it is more preferred by the active parent peptide fMLP-OMe (12 times) than for its inactive analog fML ${ }^{\mathrm{S}} \mathrm{P}-\mathrm{OMe}$ (2 times). Secondly, it confirms the importance of the $\mathrm{CO}$ (formyl) and $\mathrm{NH}$ (Leu) that has been mentioned above. Indeed in this structure, the two groups are not involved in any intramolecular hydrogen bond, which allows us to suggest them as pharmacophores responsible for the formation of the substrate-receptor complex.

Since several structures ( $\beta$ turns, $\gamma$ turns and extended) have been proposed for active fMLP analogs, and given the great importance of the two pharmacophores $\mathrm{CO}$ (formyl) and $\mathrm{NH}$ at position 2 demonstrated in this study, we can suggest that in the molecular recognition process it is the "Induced fit" model of Burgen which applies. ${ }^{55,56}$ According to this model, there is no requirement for a molecule to take a specific secondary structure ( $\beta$ turn, $\gamma$ turn or extended....), because any conformer, within reasonable limits, can be extracted from the solution and bound by the receptor. For the fMLP active analogs, we suggest that the substrate binds in a first step with the receptor proposing the CO formyl (necessary but not sufficient condition), after several conformational changes for both receptor and substrate, this latter proposes the determinant $\mathrm{NH}$ group at position 2 for the constructive interaction with the receptor. The absence of structural data from studies of the interaction of fMLP with its receptors makes a docking study necessary to validate the proposed model and confirm the importance of these two groups in the molecular recognition process.

\section{Conclusion}

The comparative conformational study of $\mathrm{fM}$ LP-OMe and its analog $\mathrm{fML}^{\mathrm{S}} \mathrm{P}-\mathrm{OMe}$ described in present work allowed us to deduce three fundamental aspects concerning the structural requirements of fMLP analogs receptors.

a) The $\gamma$ turn structure centered on the central residue seems to be the native structure of the chemotactic peptide analogs.

b) The $\mathrm{CO}$ (formyl) and $\mathrm{NH}$ at position 2 must be free of any intramolecular hydrogen bond and available for a constructive interaction with the receptor.

c) The inactive analog $\mathrm{fML}^{\mathrm{S}} \mathrm{P}-\mathrm{OMe}$ prefers a $\gamma$ turn structure centered on the Met residue.

Our results and a careful examination of the recent literature enable us to suggest the "Induced-fit" model of 
Burgen in the molecular recognition process, and that the fMLP analogs activity is not related to the adoption of a specific secondary structure ( $\beta$ turn, $\gamma$ turn or extended.....), but rather to the freedom and availability of the $\mathrm{CO}$ (formyl) and $\mathrm{NH}$ group at position 2 to form the substrate-receptor complex.

Conflict of interest: The authors declare that they have no conflict of interest.

\section{References}

1. R. Snyderman, Reviews of Infectious Diseases, Fed. Proc. 1985, 7, 390-394.

2. S. Spisani, M. C. Pareschi, M. Buzzi, M. L. Colamussi, C. Biondi, S. Traniello, G. P. Zecchini, M. P. Paradisi, I. Torrini, M. E. Ferretti, Cell. Signal. 1996, 8, 269-277.

DOI:10.1016/0898-6568(96)00049-6

3. B. Belleau, G. Lajoie, G. Sauve, V. S. Rao, A. di Paola, Int. J. Immunopharmacol. 1989, 11, 467-471.

DOI:10.1016/0192-0561(89)90175-6

4. G. Cavicchioni, M. Turchetti, K. Varani, S. Falzarano, S. Spisani, Bioorg. Chem. 2003, 31, 322-330.

DOI:10.1016/S0045-2068(03)00070-1

5. M. Sukumar, P.A. Raj, P. Balaram, E.L. Becker, Biochem. Biophys. Res. Commun. 1985, 128, 339-344.

DOI:10.1016/0006-291X(85)91684-5

6. H. J. Showell, R. J. Freer, H. S. Zigmond, E. Schiffmann, S. Aswanikumar, B. Corcoran, E. L. Becker, J. Exp. Med. 1976, 143, 1154-1169. DOI:10.1084/jem.143.5.1154

7. R. J. Freer, A. R. Day, N. Muthukumaraswamy, D. Pinon, A. Wu, H. J. Showell, E. L. Becker, Biochemistry. 1982, 21, 257263. DOI:10.1021/bi00531a009

8. S. Aswanikumar, B. Corcoran, E. Schiffmann, A. R. Day, R. J. Freer, H. J. Showell, E. L. Becker, Biochem. Biophys. Res. Commun. 1977, 74, 810-817.

DOI:10.1016/0006-291X(77)90375-8

9. F. Boulay, M. Tardif, L. Brouchon, P. Vignais, Biochemistry. 1990, 29, 11123-11133. DOI:10.1021/bi00502a016

10. R. M.Freidinger, D. S. Veber, R. Hirschman, L. M. Paege, Int. J. Pept. Protein Res. 1980, 16, 464-470. DOI:10.1111/j.1399-3011.1980.tb02970.x

11. R. M. Freidinger, D. S. Perlow, D. S. Veber, J. Org. Chem. 1982, 47, 104-109. DOI:10.1021/jo00340a023

12. R. M.Freidinger, J. Med. Chem. 2003, 46, 5553-5566. DOI:10.1021/jm030484k

13. A. Perdih, D. Kikelj, Current Medicinal Chemistry. 2006, 13, 1525-1556. DOI:10.2174/092986706777442066

14. A. Perdih, M. S. Dolenc, Current Organic Chemistry. 2011, 15, 3750-3799. DOI:10.2174/138527211797884566

15. G. Sauve, V. S. Rao, G. Lajoie, B. Belleau, Can. J. Chem. 1985, 63, 3089-3101. DOI:10.1139/v85-511

16. A. G. Michel, G. Lajoie, C. Ameziane Hassani, Int. J. Pept. Protein. Res. 1990, 36, 489-498.

DOI:10.1111/j.1399-3011.1990.tb00987.x
17. H. Dugas, M. Laroche, M. Ptak, H. Labbé, Int. J. Pept. Protein. Res. 1993, 41, 595-605.

DOI:10.1111/j.1399-3011.1993.tb00482.x

18. G. Vertuani, M. Boggian, A. Breveglieri, G. Cavicchioni, S. Spisani, A. Scatturin, Amino Acids. 1995, 9, 375-383.

DOI:10.1007/BF00807274

19. G. Cavicchioni, A. Breveglieri, M. Boggian, G. Vertuani, E. Reali, S. Spisani, J. Pept. Sci. 1996, 2 , 135-140.

20. M. Iqbal, P. Balaram, H. J. Showell, R. J. Freer, E. L. Becker, FEBS Lett. 1984, 165, 171-174. DOI:10.1016/0014-5793(84)80163-5

21. R. Bardi, A. Piazzesi, C. Toniolo, P. A. Raj, S. Raghothama, P. Balaram, Int. J. Pept. Protein.Res. 1986, 27, 229-238. DOI:10.1111/j.1399-3011.1986.tb01815.x

22. C. K. Derian, H. F. Solomon, J. D. Higgins, M. J. Beblavy, R. J. Santulli, G. J. Bridger, M. C. Pike, D. J. Kroon, A. J. Fischman, Biochemistry. 1996, 35, 1265-1269. DOI:10.1021/bi952087k

23. C. Toniolo, M. Crisma, G. Valle, G. M. Bonora, S. Polinelli, E. L. Becker, R. J. Freer, R. Balaji Rao, P. Balaram, M. Sukuma, Pept.Res. 1989, 2, 275-281.

24. Y. Wazady, C. Ameziane Hassani, M. Lakhdar, A. Ezzamarty, Int. J. Mol. Sci. 2001, 2, 1-9. DOI:10.3390/i2010001

25. Y. Wazady, C. Ameziane Hassani, M. Lakhdar, A. Ezzamarty, Acta Chim. Slov. 2002, 49, 55-65.

26. G. Michel, C. Ameziane Hassani, B. Natalie, Can. J. Chem. 1992, 70, 596-603. DOI:10.1139/v92-083

27. C. Ameziane Hassani, La Génération et l’Analyse des Populations de Structures Peptidiques en Vue d'Etudier les Hypersurfaces d'Energie Conformationnelle en Mécanique Classique. Ph.D. Thesis, Université de Sherbrooke. Canada, 1991.

28. F. Lemay, C. Ameziane Hassani, A. G. Michel, Can. J. Chem. 1990, 68, 1186-1191. DOI:10.1139/v90-183

29. G. Michel, C. Jeandenans, Comput. Chem. 1993, 17, 49-59. DOI:10.1016/0097-8485(93)80028-C

30. H. Meirovitch, E. Meirovitch, A. Michel, M. Vásquez, J. Phys. Chem. 1994, 98, 6241-6243. DOI:10.1021/j100076a002

31. A. Khiat, M. Lamoureux, Y. Boulanger, J. Med. Chem. 1996, 39, 2492-2498. DOI:10.1021/jm9503254

32. C. Ameziane Hassani, M. Houssat, J. E. Hazm, Struct. Chem. 2017, 29, 481-489. DOI:10.1007/s11224-017-1045-5

33. D. E. Knuth. In "Semi-numerical algorithms." 2nd ed. Vol. 2. The art of computer programming. Addison-Wesley, Reading Mass. 1981, 3.2-3.3.

34. M. J. D. Powell. Math. Program. 1977, 12, 241-254. DOI:10.1007/BF01593790

35. G. Nemethy, M. S. Pottle, H. A. Scheraga, J. Phys. Chem. 1983,87, 1883-1887. DOI:10.1021/j100234a011

36. F. A. Momany, R. F. McGuire, A. W. Burgess, H. A. Scheraga, J. Phys. Chem. 1975, 79, 2361-2381.

DOI:10.1021/j100589a006

37. S. S. Zimmerman, M. S. Pottle, G. Némethy, H. A. Scheraga, Macromolecules. 1977, 10, 1-9.

DOI:10.1021/ma60055a001

38. R. S. Rathore, Biopolym. Pept. Sci. Sect. 2005, 80, 651-664. DOI:10.1002/bip.20231 
39. G. P. Zecchini, M. P. Paradisi, I. Torrini, G. Lucente, E. Gavuzzo, F. Mazza, G. Pochetti, M. Paci, M. Sette, A. Di Nola, G. Veglia, S. Traniello, S. Spisani, Biopolymers. 1993, 33, 437451. DOI:10.1002/bip.360330310

40. E. Morera, G. Lucente, G. Ortar, M. Nalli, F. Mazza, E. Gavuzzo, S. Spisani, Bioorganic.Med. Chem. 2002, 10, 147-157.

DOI:10.1016/S0968-0896(01)00256-5

41. S. Spisani, S. Traniello, G. Cavicchioni, F. Formaggio, M. Crisma, C. Toniolo, J. Pept. Sci. 2002, 8, 56-65.

DOI:10.1002/psc.369

42. S. Prasad, R. B. Rao, H. Bergstrand, B. Lundquist, E. L. Becker, P. Balaram, Int. J. Pept. Protein. Res. 1996, 48, 312-318. DOI:10.1111/j.1399-3011.1996.tb00847.x

43. P. A. Raj, P. Balaram, Biopolymers. 1985, 24, 1131-1146. DOI:10.1002/bip.360240703

44. G. Vertuani, S. Spisani, M. Boggian, S. Traniello, A. Scatturin, Int. J. Pept. Protein .Res. 1987, 29, 525-532.

DOI:10.1111/j.1399-3011.1987.tb02280.x

45. E. Gavuzzo, F. Mazza, G. Pochetti, A. Scatturini. J. Peptide Protein Res. 1989, 34, 409-415.

DOI:10.1111/j.1399-3011.1989.tb00710.x

46. G. Lucente, M. P. Paradisi, C. Giordano, A. Sansone, D. Torino, S. Spisani, Amino .Acids. 2008, 35, 329-338.

DOI:10.1007/s00726-007-0621-1

47. R. J. Freer, A. R. Day, J. A. Radding, E. Schiffmann, S. Aswan- ikumar, H. J. Showell, E. L. Becker, Biochemistry. 1980, 19, 2404-2410. DOI:10.1021/bi00552a019

48. C. Bismara, G. M. Bonora, C. Toniolo, E. L. Becker, R. J. Freer, Int. J. Pept. Protein .Res. 1985, 26, 482-492. DOI:10.1111/j.1399-3011.1985.tb01015.x

49. G. Cavicchioni, A. Fraulini, M. Turchetti, K. Varani, S. Falzarano, B. Pavan, S. Spisani, Eur. J. Pharmacol. 2005, 512, 1-8. DOI:10.1016/j.ejphar.2005.02.013

50. G. Cavicchioni, A. Fraulini, S. Falzarano, S. Spisani, Bioorg. Chem. 2006, 34, 298-318.

DOI:10.1016/j.bioorg.2006.07.001

51. C. Giordano, G. Lucente, A. Masi, M. P. Paradisi, A. Sansone, S. Spisani, Bioorganic .Med. Chem. 2006, 14, 2642-2652. DOI:10.1016/j.bmc.2005.11.043

52. S. Spisani, G. Cavicchioni, Bioorg. Chem. 2000, 28, 252-259. DOI:10.1006/bioo.2000.1175

53. R. Selvatici, A. Siniscalchi, S. Spisani, Rev. Med. Chem. 2013, 13, 553-564. DOI:10.2174/1389557511313040008

54. G. Cavicchioni, G. Vertuani, A. Scatturin, S. Spisani, Bioorganic. Med. Chem. Lett. 1994, 4, 1551-1554. DOI:10.1016/S0960-894X(01)80564-3

55. S. V Burgen, G. Feeny, G. C. K. Roberts, Nature. 1975, 253, 753-755. DOI:10.1038/253753a0

56. T. Nogrady, Medicinal chemistry, A biochemical approach, Oxford. University. Press. 1988, chapter 1, pp. 47-49.

\section{Povzetek}

To delo predstavlja rezultate primerjalne konformacijske analize aktivnega kemotaktičnega peptida (formil-Met-LeuPhe-OMe) in njegovega reaktivnega analoga (formil-Met-Leuభ [CSNH] Phe-OMe) z uporabo teoretičnega modela PEPSEA, katerega namen je določitev strukturnih zahtev fMLP. Študija je pokazala, da je struktura z $\gamma$ zavojem, centrirana na centralnem preostanku, nativna za analoge kemotaktičnega peptida fMLP, v katerem sta obe skupini, tako CO (formil) kot $\mathrm{NH}$ (centralni preostanek), na razpolago za interakcijo $\mathrm{z}$ receptorjem. Neaktivni analog fML ${ }^{\mathrm{S}} \mathrm{P}-\mathrm{OMe}$ pa ima namesto tega raje strukturo $\mathrm{z} \gamma$ zavojem, ki je centrirana na preostanku Met, kjer zgoraj omenjeni skupini nista dostopni za interakcijo. Naši rezultati in tisti iz literature omogočajo, da za molekularni proces prepoznavanja predlagamo »induced fit « model po Burgenu. Aktivnost fMLP analogov kemotatičnega peptida ni povezana s specifično sekundarno strukturo ( $\beta$ zavoj, $\gamma$ zavoj ali iztegnjena....), ampak z dostopnostjo CO in NH skupin na položaju 2. 